\title{
La conception de la modernité alimentaires chez les juifs de Tunisie en Israël
}

\section{Christine Balland}

\section{(2) OpenEdition \\ 1 Journals}

Édition électronique

URL : https://journals.openedition.org/tc/402

DOI : $10.4000 /$ tc. 402

ISSN : 1952-420X

Éditeur

Éditions de l'EHESS

Édition imprimée

Date de publication : 1 avril 1999

ISSN : 0248-6016

Référence électronique

Christine Balland, «La conception de la modernité alimentaires chez les juifs de Tunisie en Israël », Techniques \& Culture [En ligne], 31-32 | 1999, mis en ligne le 26 octobre 2005, consulté le 29 septembre 2022. URL : http://journals.openedition.org/tc/402 ; DOI : https://doi.org/10.4000/tc.402

Ce document a été généré automatiquement le 29 septembre 2022.

Tous droits réservés 


\section{La conception de la modernité alimentaires chez les juifs de Tunisie en Israël}

Christine Balland 